\title{
MARCH 1970
}

TENTH YEAR - No. 108
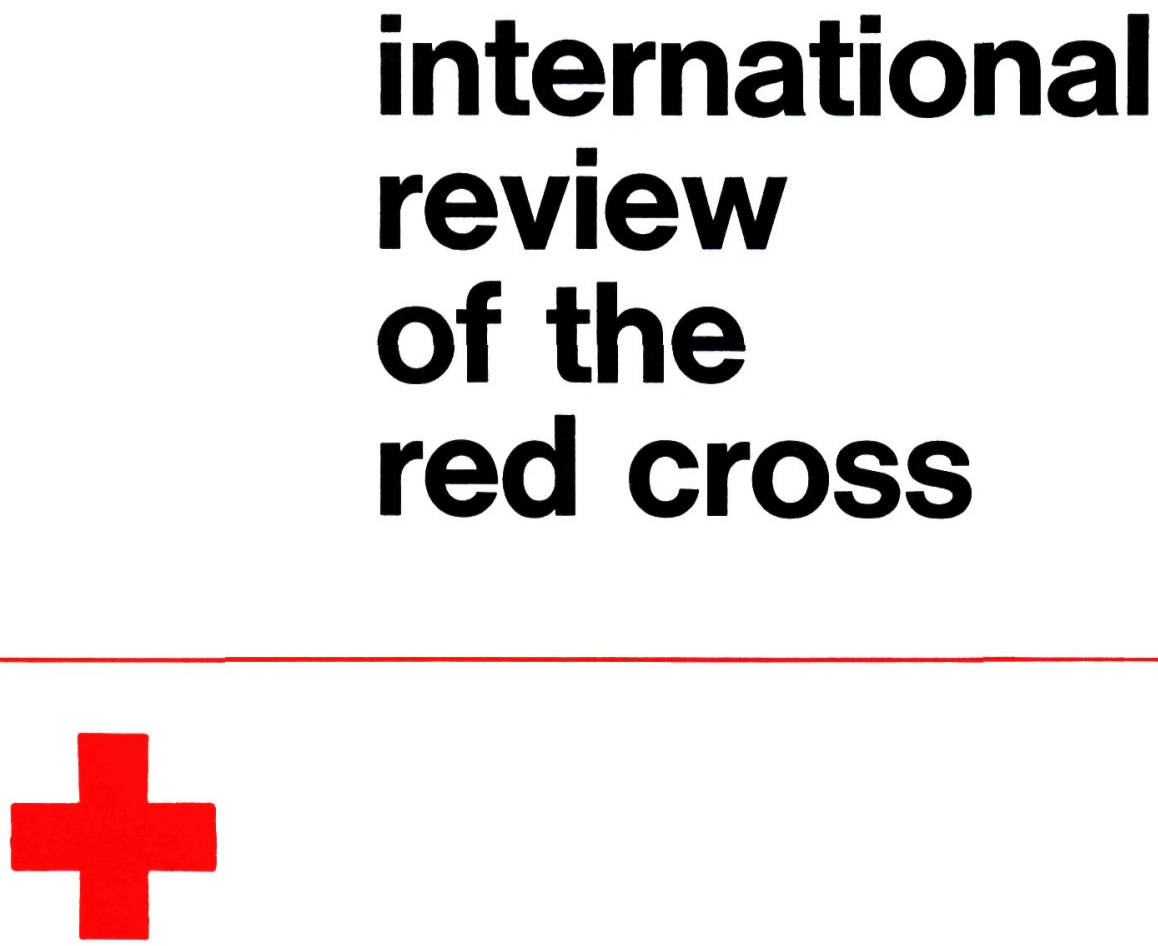

INTER ARMA CARITAS

GENEVA

INTERNATIONAL COMMITTEE OF THE RED CROSS FOUNDED IN 1863 


\section{INTERNATIONAL COMMITTEE OF THE RED CROSS}

MARCEL A. NAVILLE, Master of Arts, President (member since 1967)

MARTIN BODMER, Hon. Doctor of Philosophy (1940)

PAUL RUEGGER, former Swiss Minister to Italy and the United Kingdom, Member of the Permanent Court of Arbitration, The Hague (1948)

RODOLFO OLGIATI, Hon. Doctor of Medicine, former Director of the Don Suisse (1949)

GUILLAUME BORDIER, Certificated Engineer E.P.F., M.B.A. Harvard, Banker (1955)

HANS BACHMANN, Doctor of Laws, Assistant Secretary-General to the International Committee of the Red Cross from 1944 to 1946, Vice-President (1958)

JACQUES FREYMOND, Doctor of Literature, Director of the Graduate Institute of International Studies, Professor at the University of Geneva, Vice-President (1959)

DIETRICH SCHINDLER, Doctor of Laws, Professor at the University of Zurich (1961)

HANS MEULI, Doctor of Medicine, Brigade Colonel, former Director of the Swiss Army Medical Service (1961)

MARJORIE DUVILLARD, Deputy executive director of the International Council of Nurses (1961)

MAX PETITPIERRE, Doctor of Laws, former President of the Swiss Confederation (1961)

ADOLPHE GRAEDEL, former member of the Swiss National Council; Secretary-General of the International Metal Workers Federation (1965)

DENISE BINDSCHEDLER-ROBERT, Doctor of Laws, Professor at the Graduate Institute of International Studies (1967)

JACQUES F. DE ROUGEMONT, Doctor of Medicine (1967)

ROGER GALLOPIN, Doctor of Laws, former Director-General (1967)

JEAN PICTET, Doctor of Laws, staff member since 1937, former Director-General (1967)

WALDEMAR JUCKER, Doctor of Laws, Secretary, Union syndicale suisse (1967)

HARALD HUBER, Doctor of Laws, Federal Court Judge (1969)

Honorary members: Mr. JACQUES CHENEVIËRE, Honorary Vice-President; Miss LUCIE ODIER, Honorary Vice-President; Messrs. FREDERIC BARBEY, CARL J. BURCKHARDT, PAUL CARRY, Miss SUZANNE FERRIERE, Mrs. MARGUERITE GAUTIER-VAN BERCHEM, Messrs. SAMUEL A. GONARD, EDOUARD de HALLER, PAUL LOGOZ, FREDERIC SIORDET, ALFREDO VANNOTTI, ADOLF VISCHER. 


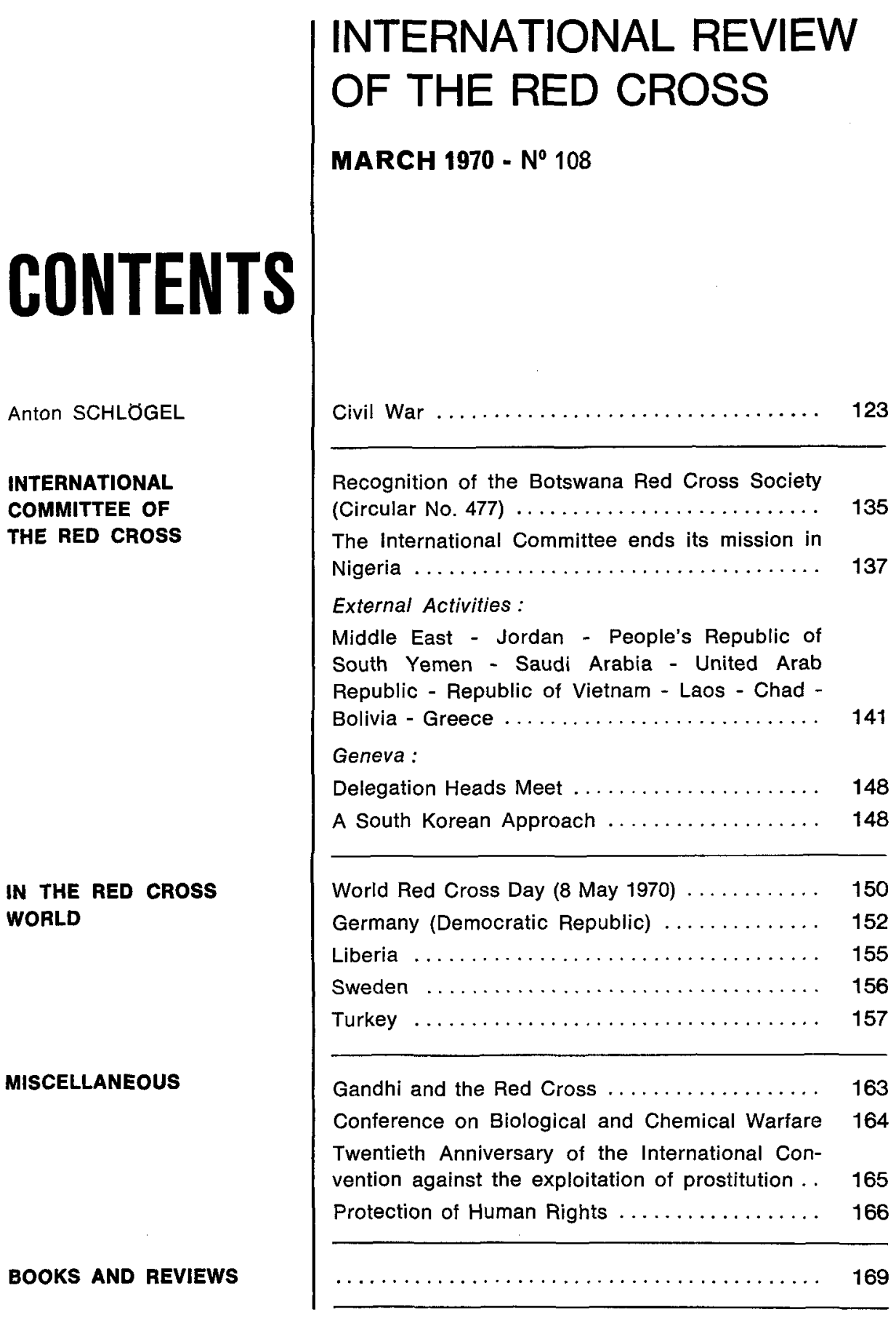




\section{FRENCH EDITION \\ OF THE REVIEW}

\section{SUPPLEMENTS}

TO THE REVIEW

SPANISH

\section{GERMAN}

INTERNATIONAL REVIEW OF

THE RED CROSS
The French edition of this Review is issued every month under the title of Revue internationale de la Croix-Rouge. It is, in princlple, identical with the English edition and may be obtained under the same conditions.

Se reconoce a la Sociedad de la Cruz Roja de Botswana - El Comité Internacional pone término a su misión en Nigeria - La acción del CICR en el conflicto entre Honduras y El Salvador (de julio a octubre de 1969) - Día Mundial de la Cruz Roja (8 de mayo de 1970).

Hans Meuli : Die Ärzte und das Rote Kreuz - Anerkennung des Botswanischen Roten Kreuzes - Das Internationale Komitee stellt seine Aktion in Nigeria ein - Welttag des Roten Kreuzes (8. Mai 1970).

The International Review is published each month by the International Committee of the Red Cross

7, avenue de la Paix, 1211 Geneva I, Switzerland Postal Cheque No. 121767

Annual subscription: Sw. fr. 25.- (\$6)

Single copies $S w$. fr. $2.50(\$ 0.60)$

Editor: J.-G. LOSSIER

The International Committee of the Red Cross assumes responsibility only for material over its own signature. 